\title{
Osmolality and composition of the extender during the cold storage of Prochilodus lineatus (Characiformes: Prochilodontidae) sperm
}

\author{
Ana T. M. Viveiros, Tais R. Taffarel and Marcelo C. Leal
}

This study evaluates the effects of extender osmolality and composition on the cooling of Prochilodus lineatus sperm. Sperm was diluted in six extenders: two compositions (powdered coconut water ${ }^{\mathrm{TM}}=\mathrm{ACP}$; Beltsville Thawing Solution ${ }^{\mathrm{TM}}=\mathrm{BTS}$ ) $\mathrm{x}$ three osmolalities $\left(285,325\right.$, and $365 \mathrm{mOsm} / \mathrm{kg}$ ) plus an undiluted control, and stored at $6-8^{\circ} \mathrm{C}$. Motility rate and velocities (curvilinear, straight line, and average path) were determined every other day. Osmolality did not affect the quality of cooled sperm, thus data were pooled. Motility was higher on d 0 compared to the other days and diluted samples (85-90\%) yielded higher motility than control (75\%). On d 2, motility was higher in BTS-diluted samples and control, but on d 4 and 6 , control yielded the highest motility. Velocities decreased from d 0 to 6 in diluted samples, but not in control. On d 0, velocities were higher in BTS-diluted sperm, but, on d 2, 4, and 6, control yielded higher velocities despite of the large variation among males. Thus $P$. lineatus sperm should be stored in BTS or without dilution, for a maximum of two days at $6-8^{\circ} \mathrm{C}$. Extender osmolality between 285 and $365 \mathrm{mOsm} / \mathrm{kg}$ does not affect sperm quality during cold storage.

Neste trabalho avaliou-se os efeitos da osmolalidade e da composição do diluidor no sêmen de Prochilodus lineatus, após o resfriamento. O sêmen foi diluído em seis diluidores: duas composições (água de coco em pó ${ }^{\circledR}=$ ACP; Beltsville Thawing Solution $\AA=$ BTS $)$ x três osmolalidades $(285,325$ e $365 \mathrm{mOsm} / \mathrm{kg})$ mais uma alíquota sem diluição como controle e armazenadas a $6-8^{\circ} \mathrm{C}$. A taxa de motilidade e velocidades (curvilinear, retilinear e média de percurso) foram determinadas a cada dois dias. A osmolalidade não afetou a qualidade do sêmen resfriado, dessa forma foi feito um 'pool' desses dados. A motilidade foi maior no d 0 comparado aos outros dias e as amostras diluídas (85-90\%) apresentaram as maiores motilidades do que o controle (75\%). No d 2, a motilidade foi maior nas amostras diluídas em BTS e controle, mas nos d 4 e 6 , o sêmen controle apresentou as maiores motilidades. As velocidades diminuíram do d 0 para o d 6 nas amostras diluídas, mas não no controle. No d 0, as velocidades foram maiores nas amostras diluídas em BTS, mas, nos d 2, 4 e 6, o controle apresentou as maiores velocidades apesar da grande variação entre os machos. Assim, o sêmen de P. lineatus deve ser resfriado em BTS ou sem diluição (controle), por no máximo dois dias a $6-8^{\circ} \mathrm{C}$. A osmolalidade do diluidor entre 285 e $365 \mathrm{mOsm} / \mathrm{kg}$ não afeta a qualidade do sêmen durante o resfriamento.

Key words: CASA, Cooling, Motility, Semen, Velocity.

\section{Introduction}

The streaked prochilod Prochilodus lineatus (Valenciennes, 1836) is a migratory Characiformes fish species, with a large geographical distribution throughout South America, accounting for up to $50-90 \%$ of the total fish biomass in the lower stretches and in the flood plain lagoons of the Paraná River basin (Bonetto, 1986; Cordiviola de Yuan, 1992). Prochilodus lineatus larvae serve as prey for carnivorous fish species and adult fish are used for human consumption, especially in northeastern Brazil. Furthermore, as artificial reproduction methods are well established and prolificacy is high, P. lineatus has been used as a model in a number of studies addressing nutrition, health, genetic diversity and reproduction (Orfão et al., 2010).

Cold storage of fish sperm is a simple technique that prolongs sperm availability for a few days, improves the genetic quality of the resulting offspring, facilitates hatchery operations by reducing the need for frequent collections of sperm, enables the transportation of genetic material across short distances and can be easily introduced to the aquaculture industry and conservation organizations (Stoss, 1983; Ciereszko \& Dabrowski, 1994). However, this method is used in only a few fish farms, mainly due to the limited

UFLA, Universidade Federal de Lavras, Departamento de Zootecnia. Caixa postal 3037, 37200-000 Lavras, MG, Brazil. anatmviveiros@hotmail.com (corresponding author); tais.regina.taffarel@gmail.com, marcelocleal@yahoo.com.br 
storage period. According to Marques \& Godinho (2004), it is important that sperm has at least $30 \%$ of motility rate in order to ensure a satisfactory fertilization. However, motility decreases fast after cooling and that rate is achieved after a few days in Characiformes fish species (Maria et al., 2006; Oliveira et al., 2007).

The addition of extenders may stabilize sperm conditions and suppress the initiation of motility during storage, overcome the problem of desiccation and reduce bacterial growth. The lifespan of spermatozoa could therefore be prolonged (Stoss, 1983). In our previous study (Orfão et al., 2010), P. lineatus sperm cooled in Beltsville Thawing Solution ${ }^{\mathrm{TM}}$ (BTS) at 332 $\mathrm{mOsm} / \mathrm{kg}$ yielded a motility rate above $60 \%$ after four days, while no motility was observed for undiluted control samples. Recently it has been shown that the powdered coconut water ${ }^{\mathrm{TM}}$ (ACP) at $300 \mathrm{mOsm} / \mathrm{kg}$ is a great extender for the sperm cryopreservation of P. lineatus (Viveiros et al., 2010b), Brycon orbignyanus and Leporinus obtusidens (Viveiros et al., 2008), Colossoma macropomum (Vieira, 2010) and Cyprinus carpio (Carvalho, 2013). However, this extender has been evaluated during the cold storage of sperm only for C. macropomum (Oliveira, 2012).

Most of fish spermatozoa are immotile in the seminal tract and hyposmotic media initiate sperm motility from freshwater fish species (Morisawa \& Suzuki, 1980). Studies regarding the effects of osmolality on the suppression of sperm motility are necessary to establish standard extenders (also called immobilizing media) for improving both artificial fertilization and preservation techniques (Alavi et al., 2009). In our previous study (Gonçalves et al., 2013) P. lineatus sperm was exposed to solutions at osmolalities ranging from 45 to $450 \mathrm{mOsm} / \mathrm{kg}$. Motility was suppressed in solutions at $360 \mathrm{mOsm} / \mathrm{kg}$ or greater. In those males, seminal plasma osmolality ranged from 276 to $346 \mathrm{mOsm} / \mathrm{kg}$.

The aim of the present study was to evaluate the effects of osmolality and composition (ACP and BTS) of the extender on sperm motility and velocities of Prochilodus lineatus, after six days of cold storage.

\section{Material and Methods}

\section{Fish handling and sperm collection}

All fish were handled in compliance with the guidelines for animal experimentation described by Van Zutphen et al. (2001). Prochilodus lineatus males were selected from the Fish Culture Station of the Minas Gerais Power Company (CEMIG)

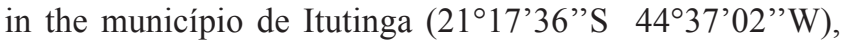
State of Minas Gerais, Brazil, during the spawning season (December to January). Males $(n=15)$ with detectable running sperm under soft abdominal pressure received two intramuscular doses of carp pituitary extract (cPE; Argent
Chemical Laboratories, Redmond, Washington, USA) at 0.4 and $4 \mathrm{mg} / \mathrm{kg}$ BW with a 12-h interval, according to the routine method of the Fish Culture. After 7.5-8 h, at water temperature of $27-28^{\circ} \mathrm{C}$, the urogenital papilla was carefully dried and approximately $2 \mathrm{~mL}$ of sperm were hand stripped directly into glass tubes. Contamination of sperm with water, blood, feces or urine was carefully avoided. Immediately after collection, the tubes were placed in a cooler $\left(9-11^{\circ} \mathrm{C}\right)$ containing dry ice foam (Polar Technics CRI Ltd., São Paulo, Brazil).

\section{Evaluation of fresh sperm}

Due to the great number of analyses, sperm of five males were cold stored and analyzed per week. After collection, sperm was transported $\sim 50 \mathrm{~km}(\sim 1$ hour $)$ by car to the Laboratory of Semen Technology at Federal University of Lavras (UFLA), State of Minas Gerais, Brazil, for further evaluation. Sperm concentration (hemacytometer/Neubauer chamber, Boeco, Hamburg, Germany) was determined. After sperm centrifugation at $2000 \mathrm{~g}$ for $10 \mathrm{~min}$ (MiniStar CM610 , Shanghai, China), osmolality (Semi-Micro Osmometer K-7400, Knauer, Berlin, Germany) and pH (Digimed DM22-V1.0, São Paulo, Brazil) of the seminal plasma were measured. Sperm characteristics were evaluated at room temperature $\left(\sim 25^{\circ} \mathrm{C}\right)$.

\section{Extenders}

Six extenders comprising the combinations of two compositions (ACP and BTS) and three osmolalities (285, 325 and $365 \mathrm{mOsm} / \mathrm{kg}$ ) were prepared. Each $100 \mathrm{~g}$ of ACP (powdered coconut water; ACPTM Biotecnologia, Fortaleza, Ceará, Brazil) contains $76 \mathrm{~g}$ carbohydrates, $4 \mathrm{~g}$ total fat, 0.88 $\mathrm{g}$ minerals, vitamins and amino acids (for detailed formulae please refer to Carvalho, 2013). Each $100 \mathrm{~g}$ of BTS (Beltsville Thawing Solution, BTS ${ }^{\mathrm{TM}}$, Minitub ${ }^{\mathrm{TM}}$, Hauptstrasse, Tiefenbach, Germany) contains $79.9 \mathrm{~g}$ glucose, $12.7 \mathrm{~g}$ sodium citrate, $2.65 \mathrm{~g}$ EDTA, $2.65 \mathrm{~g} \mathrm{NaHCO}_{3}, 1.59 \mathrm{~g} \mathrm{KCl}$ and 0.5 $\mathrm{g}$ gentamycin sulfate. The $\mathrm{pH}$ of each extender ranged from 7.6 to 7.7. All the six extenders were stored in a domestic refrigerator (Consul, $220 \mathrm{~L}$, São Paulo, Brazil) at $6-8^{\circ} \mathrm{C}$ and used within $48 \mathrm{~h}$.

Sperm from each male was diluted 1:9 (100 $\mu \mathrm{L}$ sperm:900 $\mu \mathrm{L}$ extender) in each of the 6 extenders directly in $2-\mathrm{mL}$ microtubes. One aliquot of $\sim 1 \mathrm{~mL}$ of fresh sperm was kept undiluted and served as control. Then, all microtubes were closed and stored in a domestic refrigerator at $6-8^{\circ} \mathrm{C}$ for 6 days.

\section{Evaluation of cooled sperm}

Approximately $30 \mathrm{~min}$ before the beginning of analyses, sperm samples were removed from the refrigerator to equilibrate 
with room temperature. Sperm quality was evaluated after $d 0$, $\mathrm{d} 2$, d 4, and d 6 of cooling, using the CASA system (ComputerAssisted Sperm Analyzer), following the methodology described in Viveiros et al. (2013). Briefly, motility was triggered in $98 \mathrm{mOsm} / \mathrm{kg} \mathrm{NaCl}$ at $26-29^{\circ} \mathrm{C}$ directly in a Makler ${ }^{\mathrm{TM}}$ counting chamber (Sefi-Medical Instruments 1td,Haifa, Israel) to a final dilution ratio of 1:500. The Makler ${ }^{\mathrm{TM}}$ chamber was placed under a phase contrast microscope (Nikon ${ }^{\mathrm{TM}}$ ECLIPSE E200, Tokyo, Japan) at $100 \mathrm{X}$ magnification with a green filter and $\mathrm{pH} 1$ position. The microscope was connected to a video camera (Basler Vision Technologies ${ }^{\mathrm{TM}}$ A602FC, Ahrensburg, Germany) generating 100 images/s; video recording started 10 s post-activation. Each image was analyzed using the adjusted settings for fish by Sperm Class Analyzer ${ }^{\mathrm{TM}}$ software $\left(\mathrm{SCA}^{\mathrm{TM}}\right.$ 2010, Microptics, S.L. Version 5.1, Barcelona, Spain). Although the $\mathrm{SCA}^{\mathrm{TM}}$ simultaneously assesses more than 15 sperm motility endpoints, for brevity, only motility rate, curvilinear velocity (VCL), straight line velocity (VSL) and average path velocity (VAP) were considered for analysis. To determine these parameters, each individual sperm (a mean of 838 spermatozoa/ field) was followed throughout the images and sperm trajectory was calculated. We considered the minimum acceptable quality as motility rate of $30 \%$ and VCL of $100 \mu \mathrm{m} / \mathrm{s}$, for cooled sperm.

\section{Statistical Analyses}

Data are expressed as mean \pm standard deviation (SD). Statistical analyses were carried out using the computational program Statistica7.1 ${ }^{\mathrm{TM}}$ (STATSOFT, 2003). Data on sperm motility and velocities were tested for normality (ShapiroWilk Test) and homogeneity (Levene Test). Statistical significance was tested using multiple analysis of variance (MR-MANOVA), followed by the Tukey test, when applicable. The level of significance for all statistical tests was set at $5 \%(\mathrm{P}<0.05)$.

\section{Results}

\section{Fresh sperm}

The mean sperm concentration of the 15 males used in this study was $24.7 \times 10^{9}$ spermatozoa/mL; seminal plasma osmolality was $235 \mathrm{mOsm} / \mathrm{kg}$ with a $\mathrm{pH}$ of 8.50 (Table 1)

\section{Cooled sperm}

The osmolality of the extender did not affect $(\mathrm{P}>0.05)$ sperm quality after cold storage (Table 2). Because sperm cooled in extender at osmolalities ranging from 285 to 365 $\mathrm{mOsm} / \mathrm{kg}$ yielded similar results, to facilitate the description and discussion of these results, these data were pooled per extender composition (Fig. 1).
Table 1. Body weight and some fresh sperm features of Prochilodus lineatus $(\mathrm{n}=15$ males; mean $\pm \mathrm{SD}$; $\min -\max =$ minimum and maximum values) after carp pituitary treatment.

\begin{tabular}{lcc}
\hline Parameters & Mean \pm SD & Min - Max \\
\hline Body weight $(\mathrm{kg})$ & $1.4 \pm 0.5$ & $0.7-2.8$ \\
Concentration (sperm x $\left.10^{9} / \mathrm{mL}\right)$ & $24.7 \pm 3.7$ & $20.1-30.2$ \\
Seminal plasma osmolality $(\mathrm{mOsm} / \mathrm{kg})$ & $235 \pm 15$ & $220-252$ \\
Seminal plasma pH & $8.50 \pm 0.12$ & $8.22-8.77$ \\
\hline
\end{tabular}

Sperm motility rate decreased fast in all samples, and all means were higher $(\mathrm{P}<0.05)$ on $\mathrm{d} 0$ compared to the other days, in both diluted and undiluted samples (Table 2). On d 0 of cooling, samples diluted in ACP $(85 \%)$ or in BTS $(90 \%)$ yielded higher motility when compared to undiluted control samples (75\%; Fig. 1). However, on d 2, motility rate of ACPdiluted samples was lower (20\%) compared to samples diluted in BTS (40\%) and control samples (48\%). On d 4 and d 6, undiluted control sperm yielded the highest motility rate (33\%) but the variation among the 15 males was high, ranging from 11 to $75 \%$ on d 4 and from 13 to $83 \%$ on d 6 after cooling.

All velocities decreased $(\mathrm{P}<0.05)$ from $\mathrm{d} 0$ to $\mathrm{d} 6$ in samples diluted in ACP and in BTS, but not in control samples (Table 2). On d 0 , all velocities were higher in BTS-diluted sperm, but on $\mathrm{d} 2, \mathrm{~d} 4$, and $\mathrm{d} 6$, control samples yielded the highest velocities. VCL decreased from 194 to $43 \mu \mathrm{m} / \mathrm{s}$ in ACP-diluted sperm and from 236 to $86 \mu \mathrm{m} / \mathrm{s}$ in BTS-diluted sperm, VSL decreased from 94 to $6 \mu \mathrm{m} / \mathrm{s}$ in ACP-diluted sperm and from 110 to $28 \mu \mathrm{m} / \mathrm{s}$ in BTS-diluted sperm, and VAP decreased from 167 to $15 \mu \mathrm{m} / \mathrm{s}$ in ACP-diluted sperm and from 203 to $53 \mu \mathrm{m} / \mathrm{s}$ in BTS-diluted sperm, after d 6 of cooling (Fig. 1). In undiluted sperm, all velocities were similar during the cooling period; the mean values of VCL ranged from 148 to $176 \mu \mathrm{m} / \mathrm{s}$, VSL ranged from 67 to $97 \mu \mathrm{m} / \mathrm{s}$ and VAP ranged from 120 to $151 \mu \mathrm{m} / \mathrm{s}$. Again, a large variation among males was observed after 4 days of cooling; VCL ranged from 60 to $290 \mu \mathrm{m} / \mathrm{s}$ among the 15 males.

\section{Discussion}

The present study evaluated the effects of ACP and BTS solutions at different osmolalities on motility and velocities of the $P$. lineatus sperm after cold storage. Osmolality ranging from 285 to $365 \mathrm{mOsm} / \mathrm{kg}$ did not affect sperm motility or velocities. The osmolality of the seminal plasma of these males ranged from 220 to $252 \mathrm{mOsm} / \mathrm{kg}$. A number of studies reported the triggering of sperm motility by hyposmotic surrounding medium in Characiformes (Nascimento et al., 2012; Gonçalves et al., 2013) as well as in Cypriniformes (Alavi \& Cosson, 2006), Esociformes (Alavi et al., 2009), and Perciformes (Boryshpolets et al., 2009). In order to maintain sperm quality during the storage period, motility should be suppressed; 
Table 2. Motility rate and velocities (mean $\pm \mathrm{SD}$ ) of Prochilodus lineatus ( $\mathrm{n}=15$ males) sperm diluted in six extenders composed of two compositions $\mathrm{x}$ three osmolalities. Sperm was cold stored at $6-8^{\circ} \mathrm{C}$ for six days. Undiluted sperm served as control. ACP: Powdered Coconut Water ${ }^{\mathrm{TM}}$; BTS: Beltsville Thawing Solution ${ }^{\mathrm{TM}}$. There was no difference of extender osmolality on sperm quality ( $\mathrm{P}>0.05$; MR-MANOVA). * Means within the same line followed by this symbol are significantly higher than the others (comparison among days after cooling; $\mathrm{P}<0.05$; Tukey).

\begin{tabular}{|c|c|c|c|c|c|}
\hline \multicolumn{2}{|c|}{ Extender } & \multicolumn{4}{|c|}{ Cold storage (days) } \\
\hline \multirow[t]{2}{*}{ Composition } & $\mathrm{mOsm} / \mathrm{kg}$ & 0 & 2 & 4 & 6 \\
\hline & & \multicolumn{4}{|c|}{ Motility rate $(\%)$} \\
\hline \multirow[t]{3}{*}{$\mathrm{ACP}$} & 285 & $91 \pm 6^{*}$ & $20 \pm 7$ & $11 \pm 2$ & $9 \pm 4$ \\
\hline & 325 & $82 \pm 12 *$ & $20 \pm 6$ & $12 \pm 2$ & $8 \pm 1$ \\
\hline & 365 & $83 \pm 8^{*}$ & $19 \pm 5$ & $12 \pm 2$ & $8 \pm 3$ \\
\hline \multirow[t]{3}{*}{ BTS } & 285 & $93 \pm 5^{*}$ & $43 \pm 12$ & $23 \pm 6$ & $17 \pm 5$ \\
\hline & 325 & $90 \pm 7^{*}$ & $42 \pm 12$ & $25 \pm 8$ & $18 \pm 4$ \\
\hline & 365 & $88 \pm 8^{*}$ & $36 \pm 13$ & $20 \pm 6$ & $15 \pm 4$ \\
\hline \multirow[t]{2}{*}{ Undiluted sperm } & & $75 \pm 12 *$ & $48 \pm 23$ & $33 \pm 21$ & $33 \pm 21$ \\
\hline & & \multicolumn{4}{|c|}{ Curvilinear velocity $(\mu \mathrm{m} / \mathrm{s})$} \\
\hline \multirow[t]{3}{*}{ ACP } & 285 & $221 \pm 34 *$ & $96 \pm 21$ & $72 \pm 11$ & $44 \pm 13$ \\
\hline & 325 & $180 \pm 34 *$ & $88 \pm 16$ & $69 \pm 7$ & $42 \pm 5$ \\
\hline & 365 & $180 \pm 28^{*}$ & $88 \pm 10$ & $70 \pm 9$ & $44 \pm 14$ \\
\hline \multirow[t]{3}{*}{ BTS } & 285 & $244 \pm 42 *$ & $134 \pm 23$ & $104 \pm 23$ & $88 \pm 17$ \\
\hline & 325 & $239 \pm 36^{*}$ & $138 \pm 30$ & $103 \pm 18$ & $92 \pm 15$ \\
\hline & 365 & $224 \pm 43^{*}$ & $120 \pm 24$ & $87 \pm 18$ & $77 \pm 15$ \\
\hline \multirow[t]{2}{*}{ Undiluted sperm } & & $176 \pm 48$ & $179 \pm 52$ & $148 \pm 70$ & $159 \pm 60$ \\
\hline & & \multicolumn{4}{|c|}{ Straight line velocity $(\mu \mathrm{m} / \mathrm{s})$} \\
\hline \multirow[t]{3}{*}{$\mathrm{ACP}$} & 285 & $98 \pm 17^{*}$ & $34 \pm 13$ & $16 \pm 6$ & $6 \pm 4$ \\
\hline & 325 & $91 \pm 22 *$ & $30 \pm 11$ & $16 \pm 7$ & $7 \pm 4$ \\
\hline & 365 & $93 \pm 22^{*}$ & $31 \pm 9$ & $17 \pm 6$ & $6 \pm 5$ \\
\hline \multirow[t]{3}{*}{ BTS } & 285 & $107 \pm 17 *$ & $55 \pm 11$ & $40 \pm 12$ & $30 \pm 11$ \\
\hline & 325 & $110 \pm 17 *$ & $62 \pm 12$ & $43 \pm 13$ & $31 \pm 11$ \\
\hline & 365 & $112 \pm 19 *$ & $55 \pm 18$ & $33 \pm 15$ & $24 \pm 13$ \\
\hline \multirow[t]{2}{*}{ Undiluted sperm } & & $97 \pm 37$ & $77 \pm 24$ & $67 \pm 37$ & $71 \pm 26$ \\
\hline & & \multicolumn{4}{|c|}{ Average path velocity $(\mu \mathrm{m} / \mathrm{s})$} \\
\hline \multirow[t]{3}{*}{$\mathrm{ACP}$} & 285 & $190 \pm 32 *$ & $68 \pm 24$ & $35 \pm 12$ & $15 \pm 6$ \\
\hline & 325 & $159 \pm 40^{*}$ & $56 \pm 19$ & $33 \pm 8$ & $16 \pm 5$ \\
\hline & 365 & $153 \pm 27 *$ & $58 \pm 13$ & $32 \pm 9$ & $15 \pm 9$ \\
\hline \multirow[t]{3}{*}{ BTS } & 285 & $207 \pm 37 *$ & $107 \pm 23$ & $76 \pm 26$ & $57 \pm 21$ \\
\hline & 325 & $208 \pm 34 *$ & $115 \pm 30$ & $75 \pm 22$ & $60 \pm 19$ \\
\hline & 365 & $193 \pm 42 *$ & $95 \pm 26$ & $56 \pm 22$ & $43 \pm 18$ \\
\hline Undiluted sperm & & $144 \pm 51$ & $151 \pm 53$ & $120 \pm 74$ & $134 \pm 61$ \\
\hline
\end{tabular}

thereby the use of an extender at high osmotic pressure is mandatory. In the present study, the osmolalities tested were hyperosmotic compared to the seminal plasma and thus the activation of sperm motility during storage was prevented.

Unlike the reported data on the literature, motility rate observed for undiluted control sperm of $P$. lineatus was above $30 \%$ on $\mathrm{d} 4$ of cooling. It was expected that undiluted sperm quality would decrease to $0 \%$ motility due to sperm aging, sperm competition for oxygen and space, and bacterial growth, as reported for P. lineatus (Orfão et al., 2010) and Brycon orbignyanus (Maria et al., 2006). Velocities were also high and VCL ranged from 148 to $176 \mu \mathrm{m} / \mathrm{s}$ during the six days of storage. It has been reported that VCL is closely related to the fertilizing capacity of sperm (Rurangwa et al., 2001; Viveiros et al., 2010b). Thereby undiluted P. lineatus sperm could retain the capacity to fertilize oocytes for up to six days after cooling. However, due to the large variation among the 15 individual males observed on 4 of cooling (motility from 11 to $75 \%$ and VCL from 60 to $290 \mu \mathrm{m} / \mathrm{s}$ ), we recommend the use of undiluted sperm within two days.
In the present study when $P$. lineatus sperm was diluted in a solution containing antibiotic (BTS) to control bacterial growth and improve space and oxygen availability, sperm motility was only $40 \%$ after d 2 of cooling, and was not improved when compared to undiluted samples. Studies using BTS as extender during the cold storage of Characiformes sperm have reported successful results. Motility rate was $81 \%$ after d 4 of cooling in P. lineatus (Orfão et al., 2010), 48\% after d 7 in Brycon nattereri (Oliveira et al., 2007) and 43\% after d 3 in B. orbignyanus (Maria et al., 2006). BTS ${ }^{\text {TM }}$ contains gentamycin sulphate in its formulae and it has been shown that $92 \%$ of the bacterial populations in B. orbignyanus sperm are susceptible to gentamycin (Viveiros et al., 2010a). As the B. orbignyanus and $P$. lineatus specimens used in both studies were selected from the same earthen pond at CEMIG and the bacterial populations in B. orbignyanus sperm were likely derived from the environment (water, net and mucus), it is possible that the gentamycin in BTS controlled bacterial growth during the cold storage of sperm from the P. lineatus, as 
in B. orbignyanus sperm. Therefore, bacterial growth was not the cause for the decrease of sperm quality of BTSdiluted samples during storage. In all studies mentioned above, motility rate was subjectively estimated using a light microscope, rather than a more objective analysis such as the CASA system. Therefore, it is possible that the motility rate had been overestimated in those studies. Furthermore, inter and intra-species differences and rearing conditions are factors that interfere with the composition of the seminal plasma and sperm quality, and consequently, modify the sensibility of sperm to extenders and storage processes.

The powdered coconut water ${ }^{\mathrm{TM}}$ (ACP) is a standardized medium, different from the in natura coconut water. The success of ACP as an extender for the cryopreservation of fish sperm has been reported for P. lineatus (Viveiros et al., 2010b), B. orbignyanus and L. obtusidens (Viveiros et al., 2008),
Colossoma macropomum (Vieira, 2010) and Cyprinus carpio (Carvalho, 2013). However, this extender has been evaluated during the cold storage of sperm only for $P$. lineatus (present study) and for Colossoma macropomum (Oliveira, 2012). The results, however, were not as good as those observed for the cryopreservation of sperm, as, after two days of cooling, sperm diluted in ACP yielded only $20 \%$ motility and $91 \mu \mathrm{m} / \mathrm{s}$ of VCL for P. lineatus and $31 \%$ motility and $43 \mu \mathrm{m} / \mathrm{s}$ of VCL for $C$. macropomum.

In the present study, the temperature of $6-8^{\circ} \mathrm{C}$ was chosen for storage as it is the domestic refrigerator temperature, which facilitates the use of this methodology in any fish farm. Other temperatures could improve or deteriorate faster the sperm quality during storage.

Prochilodus lineatus sperm can be cold stored after dilution in BTS or without dilution, for a maximum of two
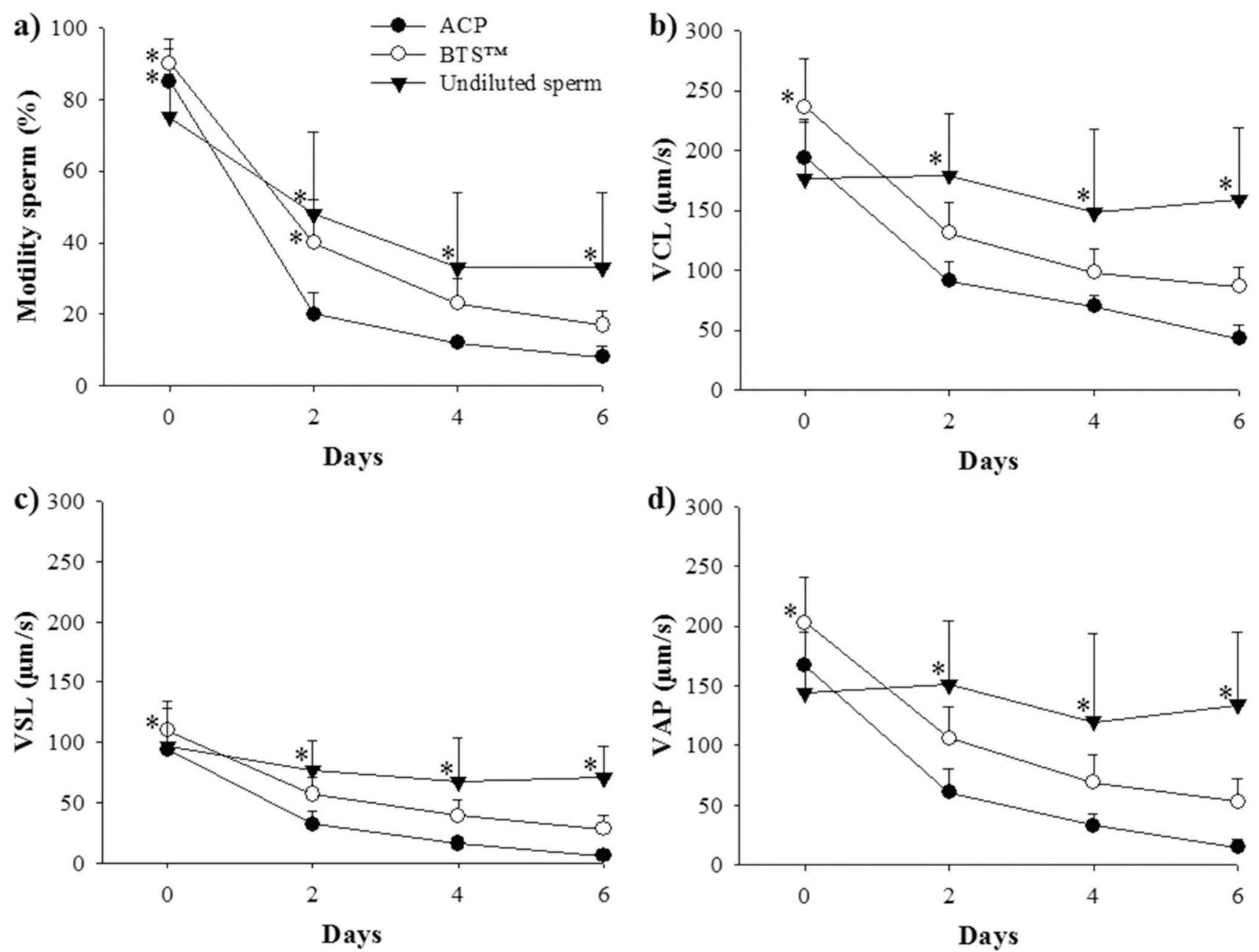

Fig. 1. Motility rate (a); curvilinear (VCL; b), straight-line (VSL; c) and average path (VAP; d) velocities of Prochilodus lineatus sperm diluted in two extender compositions ( $\mathrm{ACP}=$ closed circles; $\mathrm{BTS}=$ open circles) and stored at $6-8^{\circ} \mathrm{C}$ for six days. Undiluted sperm served as control (closed triangle). Each dot and error bar represents mean \pm SD; $n=15$ males. ACP: Powdered Coconut Water ${ }^{\mathrm{TM}}$; BTS: Beltsville Thawing Solution ${ }^{\mathrm{TM}}$. *Means followed by this symbol, within the same day of analysis, are significantly higher $(\mathrm{P}<0.05$; Tukey). 
days at $6-8^{\circ} \mathrm{C}$, to guarantee high sperm quality in most of the males. The extender osmolality between 285 and $365 \mathrm{mOsm} /$ $\mathrm{kg}$ does not affect sperm quality during cold storage.

\section{Acknowledgments}

This study received funding from the Brazilian research agencies FAPEMIG (PPM 00129-11; BPD 00167-12; PPM 00038-13) and FINEP (CPDTA UFLA 01.10.0724.00). This research is part of Tais R. Taffarel's M.Sc. Dissertation. The authors thank Thales S. França (UFLA), Lays F.R. Pereira (UFLA), D. Rossetto (UNIOESTE), Dr. Z. Dogu (Harran University Bozova, Turkey), the staff members Flávio H. Siqueira, Gilson A. Azarias, and Jailson M. Silva (CEMIG, Itutinga Unit) for assistance during the experiments, and Cristiane C. M. Salgueiro (UECE) for providing the ACP.

\section{Literature Cited}

Alavi, S. M. H. \& J. Cosson. 2006. Sperm motility in fishes. (II) Effects of ions and osmolality: A review. Cell Biology International, 30:1-14.

Alavi, S. M. H., M. Rodina, A. T. M. Viveiros, J. Cosson, D. Gela, S. Boryshpolets \& O. Linhart. 2009. Effects of osmolality on sperm morphology, motility and flagellar wave parameters in Northern pike (Esox lucius L.). Theriogenology, 72:32-43.

Bonetto, A. A. 1986. Fish of the Paraná system. Pp. 573-588. In: Davies, B. R. \& K. F. Walker (Eds.). The Ecology of River Systems. Dr W. Junk, Dordrecht, The Netherlands.

Boryshpolets, S., B. Dzyuba, V. Stejskal \& O. Linhart. 2009. Dynamics of ATP and movement in Eurasian perch (Perca fluviatilis L.) sperm in conditions of decreasing osmolality. Theriogenology, 72:851-859.

Carvalho, M. A. M. 2013. Água de coco em pó na criopreservação do sêmen de carpa comum, Cyprinus carpio L. Unpublished Ph.D. Dissertation, Universidade Estadual do Ceará, Fortaleza, 123p.

Ciereszko, A. \& K. Dabrowski. 1994. Relationship between biochemical constituents of fish semen and fertility: the effect of short-term storage. Fish Physiology and Biochemistry, 12: 357-367.

Cordiviola de Yuan, E. 1992. Fish populations of lentic environments of the Parana River. Hydrobiologia, 237: 159-173.

Gonçalves, A. C. S., A. F. Nascimento, A. C. Costa, M. C. Leal \& A. T. M. Viveiros. 2013. Initiation and suppression of sperm motility is osmolality-dependent in two South American fish species: streaked prochilod Prochilodus lineatus and piracanjuba Brycon orbignyanus. Animal Reproduction, 10: 62-70.

Maria, A. N., A. T. M. Viveiros, R. T. F. Freitas \& A. V. Oliveira. 2006. Extenders and cryoprotectants for cooling and freezing of piracanjuba (Brycon orbignyanus) semen, an endangered Brazilian teleost fish. Aquaculture, 260: 298-306.

Marques, S. \& H. P. Godinho. 2004. Short-term cold storage of sperm from six Neotropical Characiformes fishes. Brazilian Archives of Biology and Technology, 47: 799-804.

Morisawa, M. \& K. Suzuki. 1980. Osmolality and potassium ion: their roles in initiation of sperm motility in teleost. Science, 210: $1145-1147$.
Nascimento, A. F., A. C. S. Gonçalves, R. V. Reis Neto, M. C. Leal \& A. T. M. Viveiros. 2012. Extender composition, osmolality, cryoprotectant and equilibration time effects on fresh sperm motility of two Characiformes fish: piracanjuba (Brycon orbignyanus) and streaked prochilod (Prochilodus lineatus). Animal Reproduction, 9: 103-110.

Oliveira, F. C. E. 2012. Resfriamento do sêmen de Colossoma macropomum em água de coco em pó (ACP-104) associada à crioprotetores - estudo de toxicidade. Unpublished MS.c. Dissertation, Universidade Estadual do Ceará, Fortaleza, 66p.

Oliveira, A. V., A. T. M. Viveiros, A. N. Maria, R. T. F. Freitas \& Z. A. Isaú. 2007. Sucesso do resfriamento e congelamento de sêmen de pirapitinga Brycon nattereri. Arquivo Brasileiro de Medicina Veterinária e Zootecnia, 59: 1509-1515.

Orfão, L. H., A. N. Maria, A. F. Nascimento, Z. A. Isaú \& A. T. M. Viveiros. 2010. Sperm fertility of the subtropical freshwater streaked prochilod Prochilodus lineatus (Characiformes) improved after dilution and cold storage. Aquaculture Research, 41:679-687.

Rurangwa, E., F. A. M. Volckaert, G. Huyskens, D. E. Kime \& F. Ollevier. 2001. Quality control of refrigerated and cryopreserved semen using computer-assisted sperm analysis (CASA), viable staining and standardized fertilization in African catfish (Clarias gariepinus). Theriogenology, 55: 751-769.

STATSOFT, INC. 2003. Statistica: livro base (data analysis software system, version 7.1.). São Caetano do Sul, Copyright Statsoft, 142p.

Stoss, J. 1983. Fish gamete preservation and spermatozoan physiology. Pp. 305-350. In: Hoar, W. S., D. J. Randall \& E. M. Donaldson (Eds.). Fish Physiology. London, Academic Press.

Van Zutphen, L. F., V. Baumans \& A. C. Beynen. 2001. Principles of laboratory animal science - A contribution to the humane use and care of animals and to the quality of experimental results. Revised Edition. Amsterdam, Elsevier.

Vieira, M. J. A. F. 2010. Caracterização do sêmen de tambaqui, Colossoma macropomum (Cuvier, 1818), e criopreservação em diluentes a base de água de coco em pó (ACP-104). Unpublished Ph.D. Dissertation, Universidade Estadual do Ceará, Fortaleza, 115p.

Viveiros, A. T. M., Z. A. Isaú, H. C. P. Figueiredo, A. M. S. Leite \& A. N. Maria. 2010a. Gentamycin controls bacterial growth during refrigerated storage of piracanjuba, Brycon orbignyanus, semen. Journal of the World Aquaculture Society, 41: 57-65.

Viveiros, A. T. M., A. C. S. Gonçalves, I. M. Di Chiacchio, A. F. Nascimento, E. Romagosa \& M. C. Leal. 2013. Gamete quality of streaked prochilod Prochilodus lineatus (Characiformes) after GnRHa and dopamine antagonist treatment. Zygote. http://dx.doi. org/10.1017/S0967199413000440

Viveiros, A. T. M., A. N. Maria, L. H. Orfão, M. A. M. Carvalho \& J. F. Nunes. 2008. Powder coconut water $(A C P \AA)$ as extender for semen cryopreservation of Brazilian migratory fish species. Cybium - International Journal of Ichthyology, 32: 215.

Viveiros, A. T. M., A. F. Nascimento, L. H. Orfão \& Z. A. Isaú. 2010b. Motility and fertility of the subtropical freshwater fish streaked prochilod (Prochilodus lineatus) sperm cryopreserved in powdered coconut water. Theriogenology, 74: 551-556.

Submitted November 10, 2013

Accepted January 21, 2014 by Bernardo Baldisserotto

Published September 30, 2014 